Fecha de recepción: julio 2021 Fecha de aprobación: agosto 2021 Fecha publicación: septiembre 2021

\section{Toward adaptable and responsive facades: using strategies for transforming of the material and bio-based materials in favor of sustainability}

Tarciana Andrade ${ }^{(1)}$, José Nuno Beirão ${ }^{(2)}$, Amilton José Vieira de Arruda ${ }^{(3)}$ y Carolina Eysen ${ }^{(4)}$

\begin{abstract}
The current knowledge demonstrates the expansion of responsive facades' propositions resorting to biomimetic approaches, materials research, and algorithmic design. This work comprises trends in materials and technologies that contribute to the thermal and environmental control of buildings in favor of sustainability. We analysed eleven facades and installations proposals. The chosen designs meet the following criteria: presenting different reversible strategies for transforming the material and/or bio-based materials. In future works, we intend to propose new responsive facade solutions to contribute to the sustainability of buildings.
\end{abstract}

Keywords: Biomimetic and Design - Climate adaptation - Responsive Facade - Material deformation - Growing Design - Bio-based materials - Innovation - Responsive material - Sustainability.

[Abstracts in spanish and portuguese at pages 58-59]

(1) Tarciana Andrade. Degree in Design from Universidade Federal de Pernambuco-UFPE (2009) and in Business Administration from Universidade de Pernambuco (2011). Got her master's degree in design (UFPE) (2014) with research related to design strategies for innovation (design-driven innovation) and the role of meanings as a source for promoting competitiveness for the Creative Economy of Pernambuco. Coordinated the makerspace of Porto Digital (Laboratory of Connected Urban Objects-LOUCO). Currently, she is developing her Ph.D. research in Design, at the Faculty of Architecture of the University of Lisbon, on the development of the responsive Cobogó inspired by plants' movements and intensive use of parametric design adaptable to different climates. Before her Ph.D., she taught design and architecture courses in Pernambuco at UNIBRA and UNIFG (Laureate International Universities). Her research interests are: biomimetics, design computational, digital fabrication and innovation. andrade.tarci@gmail.com

(2) José Nuno Beirão. Degree in Architecture (1989) from the Faculty of Architecture, TU Lisbon. Worked at Gonçalo Byrne and João Pedro de Campos architecture offices. In 1998 founded the architecture firm Bquadrado architects - www.bquadrado.com). Master's degree in urban design (2005), at ISCTE-IUL, University Institute of Lisbon. Ph.D. 
in Urbanism and Architectural engineering + Technology at TU Delft, Netherlands, in 2012. The theme of his dissertation is the development of generative design patterns for the establishment of computational platforms for urban design. In his thesis "CItyMaker: Designing for Urban Design Grammars" the acronym CIM stands for City Information Modeling stressing the emphasis of information support in urban design. His current research interests focus on the use of parametric systems and geographic databases to investigate the following concepts: (1) measuring parameters of urbanity and morphological studies, (2) development of urban design evolutionary systems, (3) customizable systems for social housing including actions at urban plan level, (4) developing strategies for sprawl mitigation, (5) smart cities. He is currently the coordinator of the Design and Computation Group at FA-ULisboa (http://dcg.fa.ulisboa.pt/).jnb@fa.ulisboa.pt

(3) Amilton José Vieira de Arruda. Graduation in Industrial Design Product Project by UFPE (1982), Master in Design and Bionics by IED in Milan (1992), Doctorate in Ricerca in Disegno Industriale, Ph.D by University of Milan Politecnico (2002) and postdoctoral in Design and Bionics at IADE European University UNIDCOM Lisbon (2018/2019). Since 1985 professor of the UFPE Design Course. He is currently associate professor IV. He coordinates the Research Group on Biodesign and Industrial Artifacts at UFPE. Organizer together with Edgard Blucher of the [DesignCONTEXTO] series design, culture and technology essays from the following books: (2017) 1. Design and Complexity; (2017) 2. Design and Social Innovation; (2018) 3. Design, Artifacts and Sustainable Systems; (2019) 4. Narratives and Languages in the creative process in Modeling and Prototyping (in press). Always with Edgar Blucher he organizes the series [designNATUREZA] essays on design, bionics and biomimetics with the following book: (2018) Methods and Processes in Bionics and Biomimetics: the technological revolution by nature. With the publisher Insigh in (2019) we launched the following title: Topics in Design: Biomimetics, Sustainability and New Materials; and recently with Blucher (2020) the Book: Design and Bionics. Carmelo Di Bartolo and Centro Ricerche IED: esperienze memorabili da 30 protagonisti. amilton. arruda@ufpe.br (D) https://orcid.org/0000-0003-4551-4497

(4) Carolina Eysen. Degree in Architecture, from the Faculdade Federal da Bahia-Brasil. She founded the architecture firm Carolina Eysen Arquitetura (2012). MBA from FGV in Real Estate Business Management and Civil Construction (2018). Currently, she participates of the Design and Computation Group at FA-ULisboa where she is developing her Ph.D. research in Architectural engineering and Technology. Her research interests are sustainable buildings, sustainable environment and design computation. caroleysen@ gmail.com 


\section{Introduction}

Records of climate change, natural resource depletion, and urban heat island formation are increasingly recurrent. The United Nations report (IPCC, 2018) warns us of the need for rapid and unprecedented transformations to limit global warming to $1.5^{\circ} \mathrm{C}$ over the next 12 years. The prediction was to increase by $2^{\circ} \mathrm{C}$. Otherwise, society will deal with extreme phenomena of droughts, floods, and heat spikes that dramatically alter the dynamics of people and ecosystems on the planet. Among the recommendations raised was a $45 \%$ reduction in $\mathrm{CO}_{2}$ emissions (one of the leading causes of the greenhouse effect) by 2030 and the use of $85 \%$ of global electricity from renewable energy sources by 2050 .

The search for a balance between reducing energy consumption, minimizing unrestrained consumption of natural resources, and using alternative materials for construction with less impact on the biosphere, can contribute to sustainable facade solutions. Sustainable development urges for changes in the current lifestyle, in a non-imposing way, but that modifies the mode of production and promotes conscious consumption. The individual considers the local and global relations and the impacts of their actions (Gumuchdjian \& Richard, 2011).

According to Kirimtat et al. (2016), buildings in the European Union consume around $40 \%$ of total final energy and $36 \%$ of total $\mathrm{CO}_{2}$ emissions by EU member states. In Europe, one of the essential legislative instruments to improve buildings' energy efficiency is the directive 2010/31/EU (Aelenei et al., 2016). A key element in this directive are the requirements for buildings that consume almost zero energy (nZEBs) (Aelenei et al., 2016). LEED (Leadership in Energy and Environmental Design), in turn, consists of an international certification system for sustainable buildings to promote and attest to the building's commitment following the principles of sustainability for civil construction (Lotti 2015). Used in more than 160 countries, LEED considers the energy consumption of each material to optimize thermal transmission, favor natural lighting, and, consequently, reduce carbon dioxide transmissions when analyzing and qualifying a building's facades (U.S. Green Building Council, 2009).

Sustainable construction demands passive architectural solutions which have practically disappeared from contemporary architecture. The emergent spaces are indoor environments with homogeneous temperatures, which stand out for the constant use of electric cooling systems (air conditioning) or heating (Hensel, 2008; Santana Neto e Silva, 2016). We need to bear in mind that the facade is the main parameter that influences buildings' energy performance. The facade elements must be designed in such a way as to provide buildings with the necessary flexibility in terms of energy flow and thermal comfort, capable of reacting to non-continuous and variable external conditions.

Regarding thermal control of facades, the main objective is for design purposes and depending on the local climate, the following environmental for facade design application: (a) Air-allows the control of air quality and compliance; (b) Heat-offers thermal comfort for the occupants (heat gain and loss); (c) Light-maximization of natural light and protection from solar radiation; (d) Water-humidity management; (e) Energy-promoting energy for the built environment (Badarnah 2012; Kuru et al. 2019). 
Considering recent research in biomimetics and materials (Fiorito et al., 2016), facades have some purposes: to expand the capacity to respond to environmental conditions; reduce energy consumption while promoting sustainability (Benyus, 2012); and minimize the use of mechanical and electronic devices, associated with computational design (Menges and Ahlquist, 2012). In that:

[...] the envelope of a building must be considered more like the skin of an organism, which has an ecological relationship with its environment, so it needs to act as a dynamic mediator between the two environments (internal and external) and less like the impenetrable wall of an ignorant capsule around you (Sung, 2016, p. 96).

Therefore, adopting adaptive and responsive facade methodologies offers opportunities for significant reductions in the use of construction energy and $\mathrm{CO}_{2}$, preserving thermal comfort in built environments.

The present study is part of ongoing doctoral research, its objective is to use a biomimetic approach to create responsive modules based on an analogy with plant movements. The article will present a qualitative analysis of eleven projects, among facades and installations. The objective is to understand trends in materials and technologies, based on: (a) different material deformation strategies that provide kinetic responses to the facades (Charpentier et al., 2017); and (b) the potential of bio-based materials, in view of Growing Design, which consists of the practice that originates from advances in biotechnology, in which materials are grown from living organisms, such as bacteria, algae or fungi (Karana et al., 2018). To replace conventional materials, they frequently use Bio-based materials (Karana et al., 2018), research points to explore orienting growth methods based on the material's inherent characteristics (Estévez, 2020). Thus, we aim to discuss trends in materials and technologies that can contribute to the thermal and environmental control of buildings to develop sustainable facades.

\section{Methodology}

Based on the studies of Charpentier et al. (2017) and Kuru et al. (2019), we defined the parameters presented in Table 1 to analyze eleven selected projects to trace technological and material development trends.

For that, we established the following criteria for selecting the corpus of projects to analyze, namely: (a) published and open access available projects; (b) completed in the last ten years (2011-2021); (c) fulfilled the least developed phase defined in the scope of this investigation as a Preliminary Model (with digital representations of how the mechanism works and not just schematic conceptual illustrations); (d) presented different material deformation strategies under biomimetic approaches, responsive materials and / or bio-based materials; and (e) presented accessible data on the materials. 
We performed a qualitative analysis of the solutions concerning the four primary characteristics: (a) scale, (b) adaptability, (c) biomimetic, and (d) materials (Charpentier et al. 2017; Kuru et al. 2019) (See Table 1).

\section{LAYER}

SCOPE

\section{PARAMETERS}

\begin{tabular}{|c|c|c|c|}
\hline \multirow[t]{3}{*}{$\begin{array}{l}\text { Layer } 1 \\
\text { Scale }\end{array}$} & Spatial scale & $\begin{array}{l}\text { FSC } \\
\text { FC }\end{array}$ & $\begin{array}{l}\text { Facade sub-component } \\
\text { Facade component }\end{array}$ \\
\hline & Developmental stage & $\begin{array}{l}\text { PM } \\
\text { SM } \\
\text { PSP }\end{array}$ & $\begin{array}{l}\text { Preliminary model } \\
\text { Simulated model } \\
\text { Pilot-scale prototype }\end{array}$ \\
\hline & & FSA & Full-scale application \\
\hline \multirow[t]{3}{*}{$\begin{array}{l}\text { Layer } 2 \\
\text { Adaptability }\end{array}$} & $\begin{array}{l}\text { Environmental } \\
\text { regulation }\end{array}$ & $\begin{array}{l}\text { H } \\
\text { L } \\
\text { A } \\
\text { W } \\
\text { E }\end{array}$ & $\begin{array}{l}\text { Heat } \\
\text { Light } \\
\text { Air } \\
\text { Water } \\
\text { Energy }\end{array}$ \\
\hline & Function & $\begin{array}{l}\text { SH } \\
\text { VE } \\
\mathrm{H} / \mathrm{C} \\
\mathrm{IA} \\
\mathrm{HU} \\
\mathrm{ED}\end{array}$ & $\begin{array}{l}\text { Shading } \\
\text { Ventilation } \\
\text { Heating/cooling } \\
\text { Improving air quality } \\
\text { Humidity } \\
\text { Energy demand }\end{array}$ \\
\hline & Stimulus & $\begin{array}{l}\mathrm{I} \\
\mathrm{E}\end{array}$ & $\begin{array}{l}\text { Intrinsic } \\
\text { Extrinsic }\end{array}$ \\
\hline \multirow[t]{2}{*}{$\begin{array}{l}\text { Layer } 3 \\
\text { Biomimetic }\end{array}$} & Biomimetic approach & $\begin{array}{l}\mathrm{RO} \\
\mathrm{BB}\end{array}$ & $\begin{array}{l}\text { Reference Organism } \\
\text { Bio-based materials }\end{array}$ \\
\hline & Adaptation level & $\begin{array}{l}\mathrm{M} \\
\mathrm{P} \\
\mathrm{B}\end{array}$ & $\begin{array}{l}\text { Morphological } \\
\text { Physiological } \\
\text { Behavioural } \\
\end{array}$ \\
\hline \multirow[t]{2}{*}{$\begin{array}{l}\text { Layer } 4 \\
\text { Materials } \\
\text { Strategy }\end{array}$} & $\begin{array}{l}\text { Different strategies } \\
\text { for transforming }\end{array}$ & $\begin{array}{l}\text { GS } \\
\text { VMP } \\
\text { FSS } \\
\text { ES }\end{array}$ & $\begin{array}{l}\text { Geometrical strategies } \\
\text { Variation of material properties } \\
\text { Fluid incompressibility/shrinking and } \\
\text { swelling } \\
\text { Energy storage }\end{array}$ \\
\hline & Materials & & Material description \\
\hline
\end{tabular}

Table 1. Project evaluation parameters. Source: adapted from Kuru et al. (2019). 


\subsection{Layer 1: Scale-Spatial scale e Development stage (Kuru et al., 2019)}

- Spatial scale can be classified as:

a. Facade sub-component (FSC): corresponds to a subcomponent of the facade or probable facade. It can be presented on a smaller scale or be a conceptual experiment (installation);

b. Facade component (FC): part of a facade or is combined to form the facade.

- The development stage seeks to clarify whether the project was developed digitally or physically. It can be classified as:

a. Preliminary model (PM): theoretical model, developed by digital computing, without analysis;

b. Simulated model (SM): digitally modeled and tested projects;

c. Pilot-scale prototype (PSP): physical prototypes, physically or digitally tested;

d. Full-scale application (FSA): system implemented in a pavilion or building, whether it is a temporary or permanent construction.

\subsection{Layer 2: Adaptability: Determines the ability to respond to environmental fac- tors and their stimuli (Kuru et al., 2019)}

- Environmental regulation: controlled climatic factors when making a change. For example, a shading system that regulates light and heat, limits solar gains, and provides light during the day. Badarnah (2012) and Kuru et al. (2019) say that we need to manage five environmental aspects to design the building envelope, namely:

a. Air (A): responsible for managing ventilation, which is necessary in order to provide a high quality of air in indoor environments and avoid air stagnation;

b. Heat $(\mathrm{H})$ : offers thermal comfort for occupants;

c. Light (L): maximizes natural light and provides a shading system with minimized heat gain;

d. Water (W): regulates humidity, as water gain for use of condensed water in arid areas;

e. Energy (E): provides energy for the built environment.

- Function: takes into account environmental control functions, such as shading (SH), ventilating (VE), heating/cooling $(\mathrm{H} / \mathrm{C})$, improving air quality (IA), regulating humidity $(\mathrm{HU})$, and regulating energy demand (ED).

- Stimulus: can be classified as

a. Intrinsic control (I) - corresponds to self-adjusting systems, it is automatically stimulated by environmental factors such as relative humidity and temperature, without the need for a mechanical system or electricity;

b. Extrinsic control (E) - is composed of artificial systems, including sensors, processors, and/or actuators. 


\subsection{Layer 3: Biomimetic identifies the Biomimetic approach, the Organism and Ad- aptation Level (Kuru et al., 2019)}

- Biomimetic approach classified as:

a. Reference Organism (RO): uses a biological organism as a reference to propose the project;

b. Bio-based materials (BB): part of the project is the organism, integrating development as a constituent material;

- Organism: field to describe which organism was used as a reference.

- Adaptation Level is classified into three categories (Kuru et al., 2019; López et al., 2017). a. Morphological (M): related to the shape, size, and structure of an organism depending on the climatic or standard environment (surface segmentation trends). Example: biomechanics of flower petals (structure); the format of plant leaves (shape), and hydrophobic outer epidermal layers of leaves (texture); furry leaves (reflect sunlight off their surface, they are adapted to dry and hot environments);

b. Physiological (P): physiological characteristics and responses - related to chemical processes (Example: organism's response to a specific external stimulus to maintain CAM photosynthesis homeostasis [Crassulacean Acid Metabolism], as an adaptation to arid conditions to increase water use efficiency / to optimize water usage).

c. Behavioral (B): Related to how an organism acts to survive. "This type of adaptation is linked to a signal feedback system of signal and response, where behavior marks an interaction between the organism and its environment" (López et al., 2017, 697). For example, kinetic responses, such as Mimosa pudica leaf movement, reacting to different stimuli (Andrade et al., 2020).

2.4. Layer 4: Materials: seeks to identify different strategies to identify the material: materials and stimulus-responsive materials (Charpentier et al., 2017; Fiorito et al., 2016)

- Different strategies to transform the material (Charpentier et al. 2017)

a. Geometric strategies (GS): consists of the production of geometries that react efficiently to the request. It provides an ideal performance of the morphological structures, which provide maximum displacement as an output, for a minimum performance input (example: umbrella mechanism).

b. Variation of material properties (VMP), based on three strategies:

(1) continuous variations in material properties: consists of fabricating a structure from a single element (such as a hinge or spring);

(2) discontinuous variations in material properties: observed mainly in heterogeneous multilayer materials, which explore the different behaviors between the expansion of the layers, which are structurally linked, such as bimetals (Charpentier et al., 2017; DOSU Studio Architects, 2018); 
(3) material anisotropy: derives from the uneven distribution of the material in the cells (Fiorito et al., 2016). Each direction in the material has its properties, so different directions can be combined with structural properties to give different displacements to provide light and efficient structures (Charpentier et al., 2017).

c. Fluid incompressibility/shrinking and swelling (FSS): "Hydraulic structures use a fluid incompressibility, whereas pneumatic structures use air compressibility to produce displacement" (Charpentier et al., 2017, 20). The use of fluidic principles can eliminate the use of elements of traditional mechanics (such as gears and hinges); research on hydrogel composites is relevant in promoting displacement (such as $4 \mathrm{D}$ printing ${ }^{1}$ ) (Sydney Gladman et al., 2016).

d. Energy storage (ES): That is the production of displacement or force of greater intensity from energy release in a short period. It is common to have energy storage in the process of dispersing plant seeds.

According to the authors, the four kinematic amplification strategies can be combined to optimize mechanisms and amplify material displacements. For, living organisms function complexly from the particular (cellular level) until reaching the organism's inter relational complexity with the environment that circumscribes it.

- Materials: is a field to briefly describe the applied material.

\section{Analysis of facades and installations}

Table 2 presents a qualitative analysis of eleven projects, among them there are facades and installations, according to the parameters specified in Table 1. Afterward, we will briefly describe each project and then evaluate the qualitative and quantitative results. 


\begin{tabular}{|c|c|c|c|c|c|c|c|c|c|c|c|c|}
\hline \multirow[b]{2}{*}{ ชี้ } & \multirow{2}{*}{ 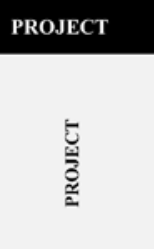 } & \multicolumn{3}{|c|}{$\begin{array}{l}\text { LAYER 1: } \\
\text { SCALE }\end{array}$} & \multicolumn{2}{|c|}{$\begin{array}{l}\text { LAYER 2: } \\
\text { ADAPTABILITY }\end{array}$} & \multirow[b]{2}{*}{$\frac{U}{2}$} & \multicolumn{2}{|c|}{$\begin{array}{l}\text { LAYER 3: } \\
\text { BIOMIMETICS }\end{array}$} & \multicolumn{2}{|c|}{$\begin{array}{l}\text { LAYER 4: } \\
\text { MATERIAL }\end{array}$} & \multirow[b]{2}{*}{$\frac{0}{0}$} \\
\hline & & 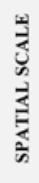 & 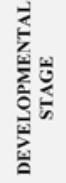 & 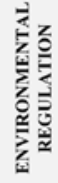 & 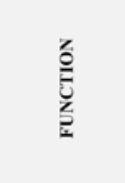 & $\frac{n}{a}$ & & 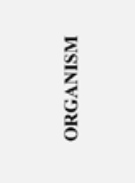 & 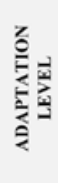 & 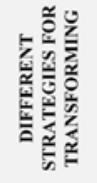 & $\begin{array}{l}\frac{\bar{k}}{\mathrm{z}} \\
\frac{\mathrm{x}}{\mathrm{N}} \\
\frac{\mathrm{c}}{2}\end{array}$ & \\
\hline P1 & Air Flower & $\mathrm{FC}$ & PSP & $\mathrm{H}, \mathrm{L}$ & $\mathrm{H} / \mathrm{C}, \mathrm{VE}, \mathrm{SH}$ & 1 & RO & $\begin{array}{l}\text { PLANT } \\
\text { Crocus } L .\end{array}$ & M & GS / VMP & Shape Memory Alloy & (Lift Architects n.d.) \\
\hline P2 & Flectofin ${ }^{\mathrm{TM}}$ & $\mathrm{FC}$ & PSP & $\mathrm{H}, \mathrm{L}$ & $\mathrm{H} / \mathrm{C}, \mathrm{VE}, \mathrm{SH}$ & $\mathrm{E}$ & RO & $\begin{array}{l}\text { PLANT } \\
\text { Strelitzia } \\
\text { reginae }\end{array}$ & M & GS/VMP & $\begin{array}{l}\text { Glass Fibre Reinforced } \\
\text { Polymer }\end{array}$ & $\begin{array}{l}\text { (Charpentier et al. } \\
\text { 2017; Lienhard et al. } \\
\text { 2012) }\end{array}$ \\
\hline P3 & Flectoflod & $\mathrm{FC}$ & FSA & L & $\mathrm{SH}, \mathrm{H} / \mathrm{C}$ & $\mathrm{E}$ & RO & $\begin{array}{l}\text { PLANT } \\
\text { Aldrovanda } \\
\text { vesiculosa }\end{array}$ & M & $\underset{/ F S S}{\text { GS/VMP }}$ & $\begin{array}{l}\text { Fibre-Reinforced Plastic. } \\
\text { Each Module has an } \\
\text { integrated Pneumatic cushion. }\end{array}$ & $\begin{array}{l}\text { (Knippers et al. } \\
2016,2018 \text { ) }\end{array}$ \\
\hline P4 & $\begin{array}{r}\text { InVert Auto- } \\
\text { Shading } \\
\text { Windows }\end{array}$ & $\mathrm{FC}$ & PSP & $\mathrm{H}, \mathrm{L}$ & $\mathrm{SH}, \mathrm{H} / \mathrm{C}$ & 1 & - & - & - & $\begin{array}{l}\text { GS / } \\
\text { VMP }\end{array}$ & Thermobimetal & $\begin{array}{l}\text { (DOSU Studio } \\
\text { Architects 2018) }\end{array}$ \\
\hline P5 & $\begin{array}{r}\text { Homeostatic } \\
\text { Facade System }\end{array}$ & $\mathrm{FC}$ & PSP & $\mathrm{L}$ & $\mathrm{SH}, \mathrm{H} / \mathrm{C}$, & $\mathrm{E}$ & RO & $\begin{array}{l}\text { GENERIC } \\
\text { Muscles and } \\
\text { homeostasis of } \\
\text { biological } \\
\text { systems }\end{array}$ & B & FSS & $\begin{array}{l}\text { Elastomer wrapped over a } \\
\text { flexible polymer core }\end{array}$ & (AskNature, 2016) \\
\hline P6 & $\begin{array}{r}\text { Breathing } \\
\text { Skins }\end{array}$ & $\mathrm{FC}$ & FSA & $\mathrm{L}, \mathrm{A}$ & $\mathrm{SH}, \mathrm{H} / \mathrm{C}$, & $\mathrm{E}$ & RO & $\begin{array}{l}\text { GENERIC } \\
\text { Organism skins }\end{array}$ & M & FSS & Pneumatic facade system & $\begin{array}{l}\text { (Becker and Huffer } \\
2015 \text { ) }\end{array}$ \\
\hline
\end{tabular}

\begin{tabular}{|c|c|c|c|c|c|c|c|c|c|c|c|c|}
\hline \multirow[b]{2}{*}{ ठิ } & \multicolumn{2}{|l|}{ PROJECT } & \multicolumn{2}{|c|}{$\begin{array}{l}\text { LAYER 1: } \\
\text { SCALE }\end{array}$} & \multicolumn{2}{|c|}{$\begin{array}{l}\text { LAYER 2: } \\
\text { ADAPTABILITY }\end{array}$} & \multirow[b]{2}{*}{$\frac{u}{\vdots}$} & \multicolumn{2}{|c|}{$\begin{array}{l}\text { LAYER 3: } \\
\text { BIOMIMETICS }\end{array}$} & \multicolumn{2}{|c|}{$\begin{array}{l}\text { LAYER 4: } \\
\text { MATERIAL }\end{array}$} & \multirow[b]{2}{*}{$\frac{\substack{n \\
\frac{\pi}{\alpha} \\
\frac{\pi}{\alpha}}}{\alpha}$} \\
\hline & 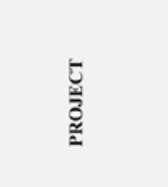 & 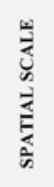 & 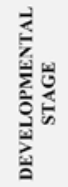 & 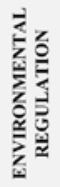 & 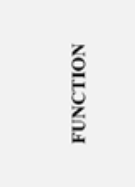 & $\sum_{\substack{n \\
\frac{2}{n}}}^{3}$ & & $\begin{array}{l}\frac{5}{5} \\
\frac{1}{2} \\
\frac{3}{0} \\
\frac{\pi}{0}\end{array}$ & 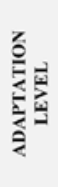 & 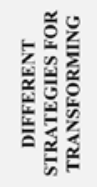 & $\frac{3}{\frac{3}{2}}$ & \\
\hline P7 & $\begin{array}{l}\text { HORTUS XL } \\
\text { Astaxanthin.g }\end{array}$ & FSC & FSA & $\mathrm{A}, \mathrm{E}$ & IA, ED & 1 & BB & $\begin{array}{l}\text { Coral } \\
\text { morphology } \\
\text { Photosynthetic } \\
\text { Cyanobacteria }\end{array}$ & $\begin{array}{l}\mathrm{M} \\
\mathrm{P}\end{array}$ & GS/VMP & $\begin{array}{l}\text { Bio-reactor is printed in } \\
\text { PETG thermoplastic and } \\
\text { Photosynthetic Cyanobacteria } \\
\text { are inoculated on a biogel } \\
\text { medium into the individual } \\
\text { triangular cells }\end{array}$ & $\begin{array}{l}\text { (EcoLogicStudio } \\
\text { 2019) }\end{array}$ \\
\hline P8 & $\begin{array}{r}\text { The } \\
\text { Growing } \\
\text { Pavilion }\end{array}$ & FSC & FSA & $\mathrm{H}, \mathrm{A}$ & IA & - & BB & Fungus & 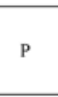 & VMP & Mycelium & $\begin{array}{l}\text { (Company New } \\
\text { Heroes and Dutch } \\
\text { Design Foundation } \\
\text { 2019) }\end{array}$ \\
\hline P9 & Hydroceramic & FC & PSP & w & $\mathrm{H} / \mathrm{C}, \mathrm{HU}$ & 1 & - & - & - & $\begin{array}{l}\text { FSS / } \\
\text { VMP }\end{array}$ & $\begin{array}{l}\text { Hydrogel composite, tissue } \\
\text { with water channel and } \\
\text { ceramic }\end{array}$ & (Rathee et al. 2013) \\
\hline P10 & $\begin{array}{r}\text { Artefato } \\
\text { gerador de } \\
\text { microclima }\end{array}$ & $\mathrm{FC}$ & PSP & w & $\underset{\mathrm{VE}}{\mathrm{H} / \mathrm{C}, \mathrm{HU}}$ & 1 & RO & $\begin{array}{l}\text { PLANT } \\
\text { Tricoma foliar }\end{array}$ & P & $\begin{array}{l}\text { FSS / } \\
\text { VMP }\end{array}$ & $\begin{array}{l}\text { Vegetal fiber, hydrogel and } \\
\text { bi-component resin of vegetal } \\
\text { origin with elastic property }\end{array}$ & (Queiroz 2015) \\
\hline P11 & $\begin{array}{r}\text { HygroSkin } \\
\text { Meteorosensitive } \\
\text { Pavilion }\end{array}$ & $\mathrm{FSC}$ & FSA & w & $\begin{array}{l}\mathrm{H} / \mathrm{C}, \mathrm{HU} \\
\mathrm{VE}\end{array}$ & 1 & RO & $\begin{array}{l}\text { PLANT } \\
\text { Cone of } \\
\text { conifers } \\
\text { (Pinophyta) }\end{array}$ & $\mathrm{P}$ & $\begin{array}{l}\text { FSS / } \\
\text { VMP }\end{array}$ & $\begin{array}{l}\text { Wood associated with } \\
\text { synthetic composites and } \\
\text { computer programming }\end{array}$ & $\begin{array}{l}\text { (Reichert, Menges, } \\
\text { and Correa 2014) }\end{array}$ \\
\hline
\end{tabular}

Table 2. Analysis of eleven projects that are inspired by nastic movements and/or exploration of responsive materials. Source: Authors. 


\subsection{Air Flow $(e r)$}

Air Flow(er) is a thermally active ventilation device made to regulate airflow and indoor temperatures, without using electricity (Lift Architects n.d.) (See Figure 1). Its design is inspired by Crocus flowers, a thermonastic organism, which is sensitive to temperature variation. The Crocus flowers open when the temperature increases and closes when it decreases, corresponding to the nastic movement typology of plants (Andrade et al., 2020). This movement comprises kinetic reactions in response to environmental stimuli, regardless of the direction (Fiorito et al., 2016; Schleicher et al., 2015).

This project uses a Shape Memory Alloy [SMA] to respond to temperature change (Lift Architects n.d.). When the building warms up beyond $27^{\circ} \mathrm{C}$, the panel system opens to allow airflow into a building. When the interior space cools down to a temperature below $16^{\circ} \mathrm{C}$, the panels gradually close to maintain the temperature at comfortable levels. This happens through the tensioning of the wires and the SMA, an instance of VMP associated with GS. According to the authors, there are three kinds of prototypes: roof opening, traditional single skin opening, and a naturally ventilated double-skin facade system. All prototypes are designed to provide natural ventilation in buildings and do not require eletric power.

\subsection{Flectofin ${ }^{\mathrm{TM}}$}

Transdisciplinary team grouping architects, engineers, and biologists at the Institute of Building Structures and Structural Design [ITKE], from the University of Stuttgart, analyzed the nastic pollination movement of the flower Strelitzia reginae and proposed Flecto$\mathrm{fin}^{T M}$ (See Figure 2), a blind system without hinges, which works through the elasticity and property of the materials, and the proper fiber disposition (Lienhard et al. 2012).

As it does not use joints, the system proposes a solution that reduces the amount of maintenance. It used the material Glass Fiber Reinforced Polymer [GFRP], which combines the high strength of glass fibers with flexible epoxy resin, in order to obtain a structural resistance to wind loads, concomitantly to the low flexural stiffness (Charpentier et al., 2017). High strength and low rigidity properties were achieved by combining the amount of layers of smooth and thin tissue with a gradual decrease of its layers, from the rigid backbone to the wing end. Thus, the fibers of the material in anisotropic disposition are essential to control deformation and allowed a capacity of dislocation up to $90^{\circ}$ near the base of the backbone, in a reversible way (VMP material deformation approach associated with GS, by anisotropy of the material). This happens through the induction of flexion efforts by displacing a bracket or altering the temperature on the blade. In addition to a wide range of calibrated elastic deformations, capable of providing kinetic and flexible structures, the modules proposed for the blind can have a lateral torsion, allowing a double curved shape during the activation of an element (Charpentier et al., 2017). 

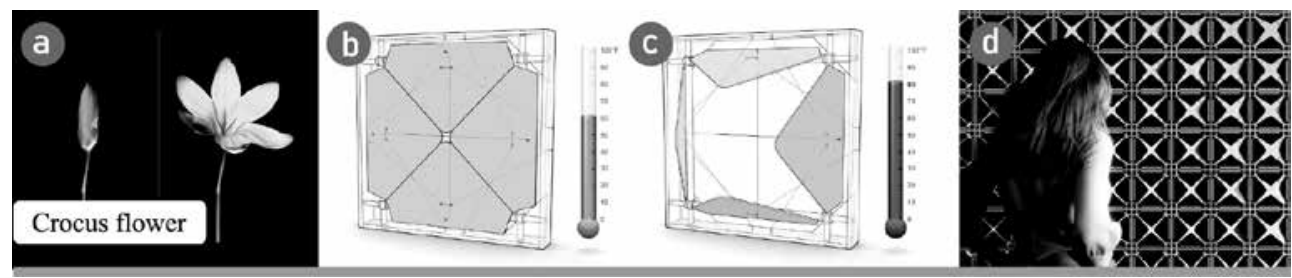

1
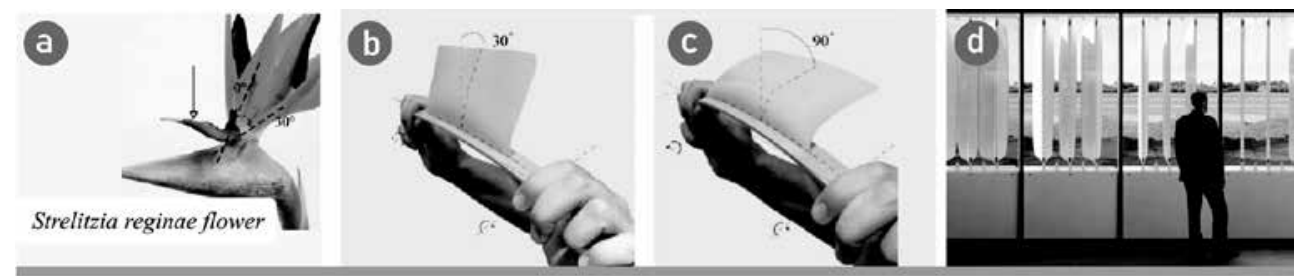

2
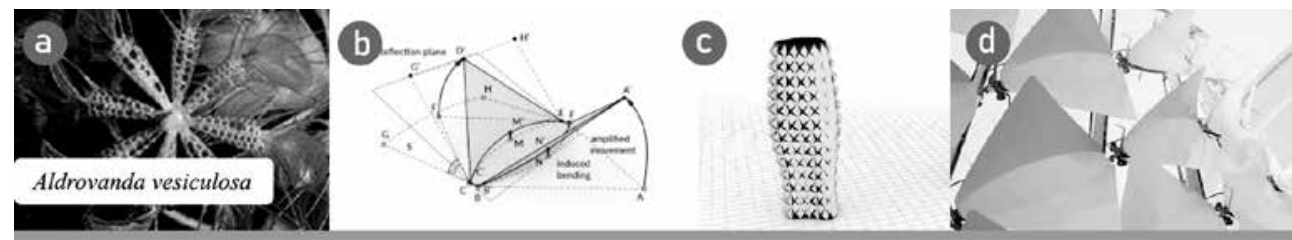

3

Figure 1. Air Flow(er) device that responds to temperature change. Source: Lift Architects, n.d. Figure 2. Flectofin ${ }^{\mathrm{TM}}$ : (a) Strelitzia reginae; (b-d) blind system without hinges. Source: Lienhard et al. 2012. Figure 3. Flectofold: (a) carnivorous plant Aldrovanda vesiculosa. (b-d) kinetic facade shading device based on the kinetic. Source: Knippers et al. 2016.

\subsection{Flectofold}

The shading device FlectoFold (See Figure 3), presented as part of the BauBionik Exhibition, at the Natural History Museum, Stuttgart, between October 2017 and May 2018, in Germany (Knippers et al., 2018), is based on the kinetic mechanism of the underwater carnivorous plant Aldrovanda vesiculosa (Knippers et al., 2016). This plant presents nastic movement (Andrade et al., 2020). 
The prototype presented a mechanism for folding and unfolding the panels made of Fiber Reinforced Plastic [FRP]. Each module has an integrated pneumatic cushion comprising an area of approximately $1 \mathrm{~m}^{2}$. Once pressurized (0.04-0.09 Bar), the cushion induces elastic flexion over the FRP laminated material body, and as a result, it generates movement and deformation. A steel substructure that integrates the pneumatic actuators fixed the modules. The control system allows the modules to be driven individually or synchronously, based on the user's active input or preprogrammed sequences.

Simulations of the folding mechanism (with pneumatic actuation) provide information on the relationship between geometric properties, performance evaluation (such as required actuation force and structural stability), and curved folding determination based on the scientific analysis of the material that influenced the positioning of the fibers. An example of VMP material anisotropy, associated with GS and FSS due to the pneumatic system).

\subsection{InVert Auto-Shading Windows}

DOSU Studio Architects (2018) developed the InVert Auto-Shading Windows (See Figure 4), a responsive facade that operates without an electro-mechanical system and in a reversible way. InVert's patented technology uses optimally designed pieces of Thermo Bimetal, a self-acting material that tends to bend when heated (bending behavior), being the "trigger" for the kinetic response to the increase of temperature on its surface (Sack-Nielsen, 2017). The explanation for such behavior consists in the composition of the material by a metallic bilayer having different coefficients of thermal expansion, causing curvature in response to rising temperatures (Sung, 2016; Vazquez, Randall, and Duarte, 2019). Cutting small in thermo bimetal pieces constitute this project, assembled in an array of individual pieces between two glass. When the pieces are positioned under the influence of the solar incidence variation they suffer an $180^{\circ}$ rotation (the bimetal piece bends, changing the point of equilibrium, therefore, enabling the reversible rotation) (See Figure 5). Such a system operates as an organic shutter system, which reduces heat gain and saves power (DOSU Studio Architects, 2018), decreasing the need for artificial air conditioning by up to $25 \%$ and reducing $\mathrm{CO}_{2}$ emissions (TDM Designs, 2020). Invert's is an example of GS associated with VMP, which explores the thermal differentiation between metal layers in order to allow displacements and deformations in the original structure so as to provide shading to the built environment.

\subsection{Homeostatic Facade System}

The technology company for architectural materials Decker Yeadon, features 'Homeostatic Facade System', which was inspired by muscles and homeostasis of biological systems. This project proposes double glass facades with an actuator that performs the system similarly to muscles and regulates a building's climate by automatically responding to environmental conditions (AskNature, 2016) (See Figure 6). 


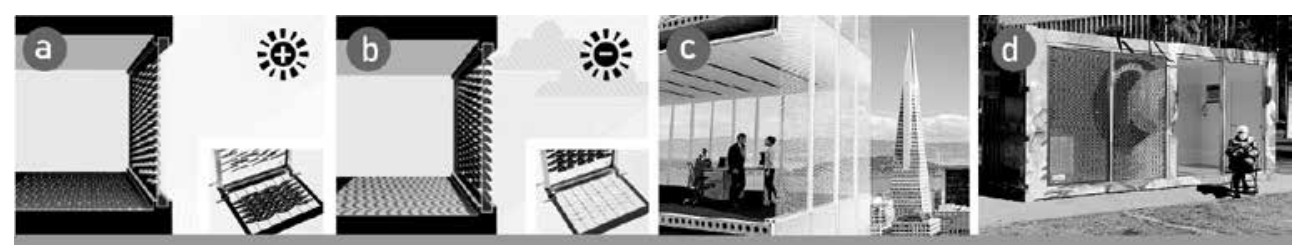

4
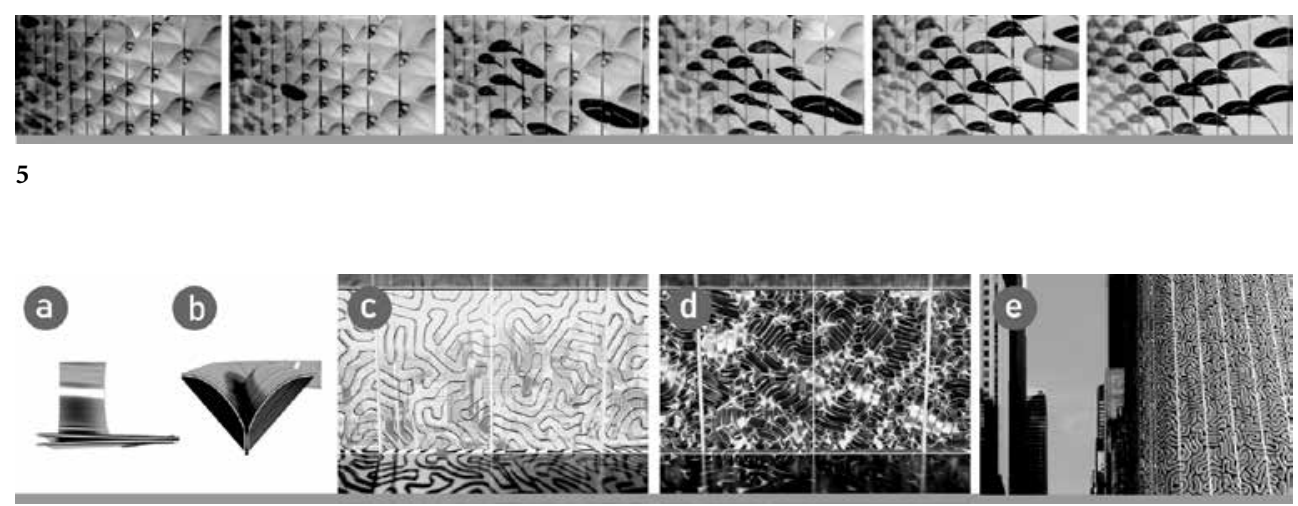

6

Figure 4. InVert Auto-Shading Windows. Source: DOSU Studio Architects 2018. Figure 5. Influence of the variation of solar incidence on thermo bimetals parts. Source: DOSU Studio Architects 2018. Figure 6. Homeostatic Facade System: (a) elastomer ribbon ( $a$ and c) closed and (b and d) open. (e) Building façade. Source: available from: https:// materialdistrict.com/article/homeostatic-facade-system/. Accessed 24 March 2021.

The system comprises an engineered ribbon inside the cavity of a double-skin glass facade. The ribbons, provide a window appearance with undulating lines, made of dielectric elastomers (polymer materials that can polarize by applying an electrical current). These materials consume very little power and are also flexible.

A silver coating on the elastomer distributes an electrical charge on its surface, causing deformations. When sunlight heats a building's interior during part of the day, the elastomer expands, creating shade inside the building. When the interior cools down, contraction occurs, allowing more light to penetrate the building's interior (AskNature 2016). 


\subsection{Breathing Skins}

Tobias Becker's Breathing Skins (See Figure 7) technology, launched in 2015, uses inspiration from the skin of organisms, which adjust their permeability to control the flow of substances, to propose a pneumatic facade system. The system breathes through thousands of pores that adjust permeability and control lighting and temperature, inside and outside the environment (Becker and Huffer, 2015).

It consists of two glass surfaces enfolding 'the pneumatic muscles.' A slight variation in pressure and energy is required to open each muscle between the two glass panels. A constant changing in the muscles' opening provides interaction with the building's internal and external environment and an aesthetic appeal. This project won several awards, such as Green Product Award 2016 and Green Product Award 2017. A possible correlation between material deformation strategies, as Charpentier et al. (2017) mentioned, and the Breathing Skins project is the incompressibility of fluids.

\subsection{H.O.R.T.U.S. XL Astaxanthin.g}

The project HORTUS XL Astaxanthin.g (See Figure 8), by EcoLogicStudio, exhibited at Centre Pompidou in Paris and the Museum of Applied Arts in Vienna, contemplates the development of an algorithm that simulates the growth of a substrate inspired by the morphology of a coral. The construction of the installation is developed on $3 \mathrm{D}$ printing of thermoplastic Polyethylene Terephthalate Glycol [PETG], whose layers are constructed with 400 microns, supported by $46 \mathrm{~mm}$ triangular units and divided into $18.5 \mathrm{~cm}$ hexagonal blocks) (EcoLogicStudio, 2019). The construction system presents reversible connections between the components, which allow for easy relocation of the prototype. According to the authors, the structure produced forms a biological reactor, having a complex morphology. Cyanobacteria, immersed in a medium composed of bio gel, are injected into individual triangular cells, which form the system's biological intelligence units. The metabolism of cyanobacteria converts radiation into oxygen and biomass, and the structure functions as a symbiotic substrate that allows the proliferation of microalgae. The porous PETG shell allows air exchange with the biological compound and obtains the necessary light to perform photosynthesis.

\subsection{The Growing Pavilion}

Dutch Design Week 2019 in the Netherlands exhibited the ecological building 'The Growing Pavilion' (See Figure 9). The creative organization Company New Heroes and the biotechnology company Krown Design produced this pavilion. It uses bio-based material consisting essentially of mycelium, a root structure of mushrooms (network of roots), which collaborate to clean the air as they grow (Company New Heroes and Dutch Design Foundation, 2019). 


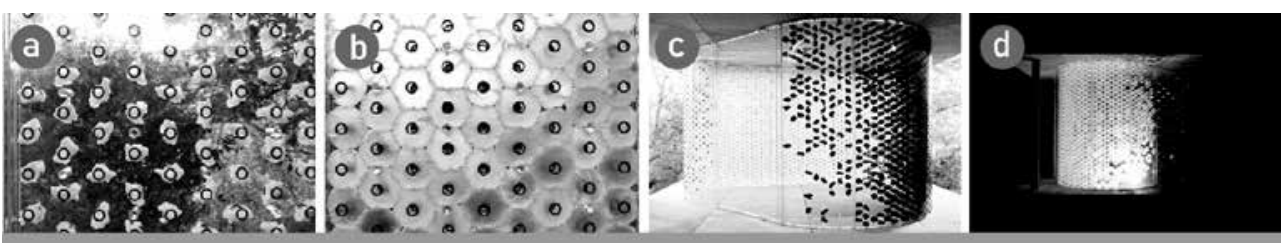

7

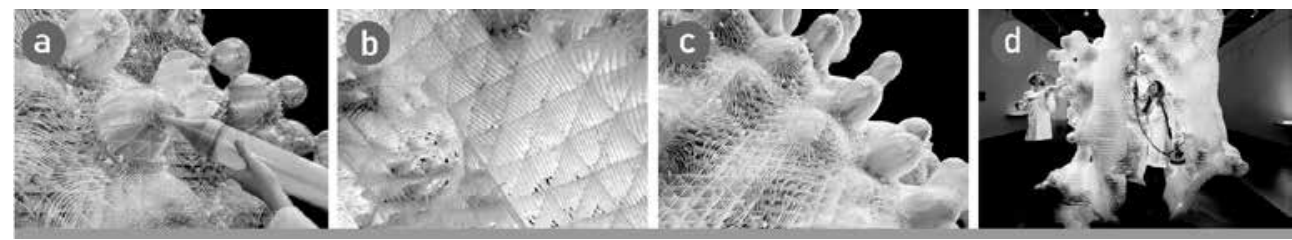

8
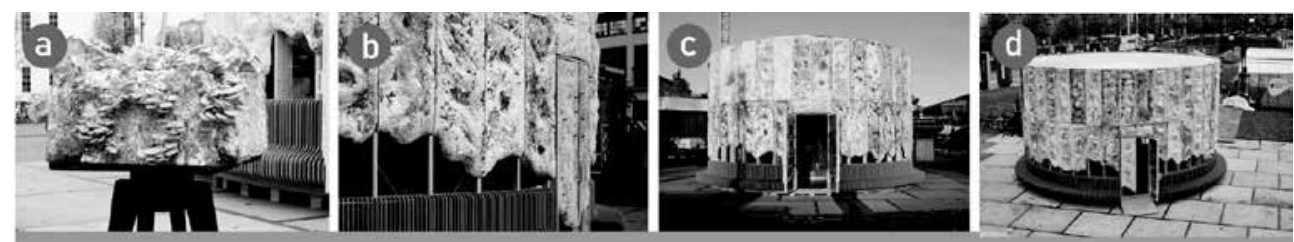

9

Figure 7. Pneumatic muscles (a) without air and (b) with air. (c and d) Prototype of Pneumatic Facade System. Source: Becker and Huffer 2015. Figure 8. Prototype H.O.R.T.U.S. XL Astaxanthin.g. Source: EcoLogicStudio 2019. Figure 9. The Growing Pavlion. Source: Company New Heroes and Dutch Design Foundation 2019. Credit images: Eric Melander and Oscar Vinck.

The mycelium can easily mold itself in any desired shape. According to Karana et al. (2018), the North American company Ecovative, founded in 2007, leads the research and development of mycelium-based materials and presents products for insulation, compostable packaging to replace styrofoam, as well as textile material resembling leather, and high-performance pure mycelium foam to replace petroleum products. It has the insulating capability and has been applied in the design of acoustic panels, bricks, and wall insulation (Estévez 2020).

The production of mycelium contributes to sustainability, as the supplier Krown.bio Design states that by producing one ton of mycelium, two tons of $\mathrm{CO} 2$ shall be captured from the atmosphere, making it possible to obtain a strong, light material, which absorbs shocks, slows down fire, and provides insulation (Grown.bio, 2020). 


\subsection{Hydroceramic}

The Hydroceramic Project (See Figure 10) aims to explore a more efficient passive cooling system for building wraps and uses hydrogel as material. The term "hydrogel" refers to a class of substances that absorb and retain 500 times their weight in water (Materiability Research Group n.d.).

The solution proposed is a passive evapotranspiration system, cooling the temperature of an interior space by $5^{\circ} \mathrm{C}$, and the capability to transfer moisture to the surrounding environment. It is responsive, as the cooling effect is greatest when the surrounding environment is humid, but little evaporation occurs when the environment is cold and dry. It used sensors to measure performance, and it does not use power for its operation.

Three parts compose this project: hydrogel, support material (the tissue as a water channel), and ceramic. This project included developing the composite material, sensitive to heat and water, seeking to combine hydrogels' evaporation property with the thermal mass and the moisture control property of ceramics and clay tissue (Rathee et al., 2013). Correlation between material deformation strategies (Charpentier et al., 2017) and Hydroceramic regards the incompressibility of fluids.

\subsection{Microclimate-generating artefacts}

Microclimate-generating artifacts (See Figure 11) contribute to mitigating the heat island effect, in hot and humid environments. It used the biomimetic approach in the design, shape parameterization, and rapid prototyping (Queiroz, 2015). The inspiration in nature arose from the understanding of how trees work by cooling naturally through the following strategies: trichomes (tissue that covers the surface of the leaf, which has high-density filaments, intensely rolled up, having a woolen aspect); evapotranspiration; photosynthesis; shading; ventilation and albedo (indicator that measures the surface reflectance of a place). It uses the principle of evaporation as a means to reduce the influence of heat. The study in question developed a proposal for three flat modules, with different porosity degrees, based on the geometric principle Voronoi. The modules were made with coconut fiber materials, associated with hydrogel and bi-component resin of vegetal origin with the elastic property. Vegetal fibers have hygroscopic characteristics and hydrogels have hydrophilic characteristics.

\subsection{HygroSkin-Meteorosensitive Pavilion}

The HygroSkin project (See Figure 12) corresponds to autonomous architectural systems that adapt themselves to environmental changes using the hygroscopic properties of materials (Reichert, Menges, and Correa 2014). According to the authors, hygroscopy corresponds to the capability to absorb the material and release moisture into the atmosphere in order to maintain a relative balance within the surrounding environment. 


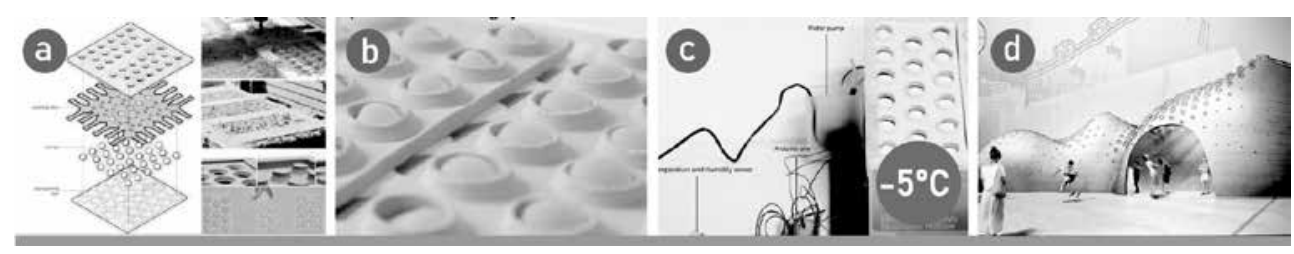

10

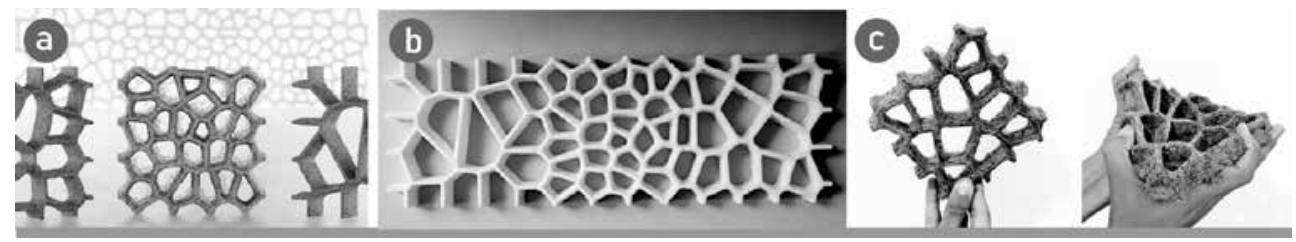

11

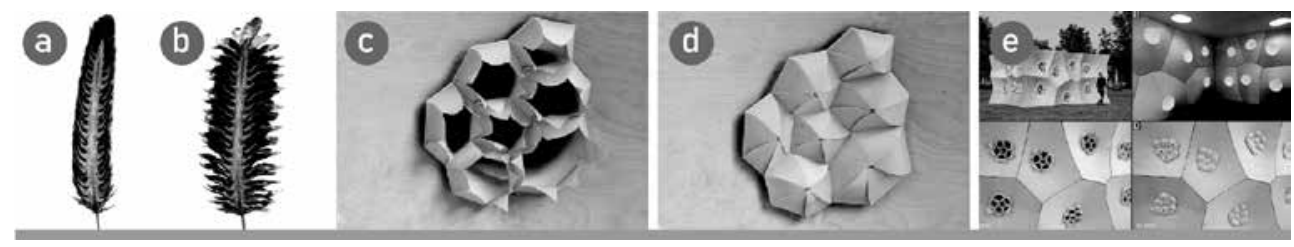

12

Figure 10. Hydroceramic Project. Source: available from: https://www.designboom.com/architecture/iaac-dmichydroceramic-passive-cooling-system-09-18-2014/. Accessed 20 June 2020. Figure 11. (a) Rendering. (b) Modular elements printed in 3D powder, on a Zprinter 310 plus. (c) Small scale prototypes, with flexible composite material. Source: Queiroz 2015. Figure 12. HygroSkin Project: (a) Cone of conifers. Responsive apertures (b) open and (c) close. (d) Temporary outdoor exhibit at Stadtgarten, Stuttgar. Source: Reichert, Menges, and Correa 2014.

The solution used a cone of conifers (Pinophyta) as a biomimetic reference organism, which in the presence of moisture alters the cone bracts behaviour (closing themselves when in contact with water and getting to open as they dry). The directional component at the wood cellular level influences the material's anisotropy, being the principle for the action of the material, using two layers of wood veneer with different swelling capacities to allow a reversible movement without the need for any electromechanical actuation (Sack-Nielsen, 2017). Such material is also associated with a synthetic composite mixture of glass fiber and epoxy bonding, allowing for the application of a consistent material thickness and the ability to maintain a constant material quality.

The researchers develop the computational design to produce programmable material for responding to different humidity ranges, with subsequent execution using digital fabrica- 
tion, to compose the programmable veneer-hybrid system (Reichert, Menges, and Correa, 2014). Thus, Hygroskin closes under high relative humidity levels and reopens due to the influence of humidity and air temperature. Result achieved from manipulating the fabrication parameters of the reactive veneer composite, making it possible to calibrate the material to react within a specific humidity range.

\section{Results}

Our analysis presented different technologies and material solutions that contribute to building sustainability through experimental research with alternative materials for construction. We will demonstrate the results regarding the quantitative and qualitative analysis. The corpus quantitative analysis identified that $66.7 \%$ of nature's organisms, including plants, animals (skin, muscles, and corals), and fungi have inspired the proposals. Three solutions used the plant's nastic movement as reference in order to provide reversible movements in response to environmental conditions, either to: provide shade, illuminate and/or ventilate. Around $16.7 \%$ of the projects used bio-based materials from living (Cyanobacteria) or dead (Mycelium) tissue. Possibly, we can use these materials in the design of facades, because Cyanobacteria function as natural bioreactors and the mycelium contributes to cleaning the air (during the growth phase of the fungus), supplying thermal insulation, and zero-carbon in cities. Such material, however, is not kinetic building solution. The remaining $16.7 \%$ did not use a reference from nature.

Most part of the solutions addressed more than one environmental factor, the majority of the proposals aimed at responding to light, followed by heat, water, air, and energy (See Graph 1).

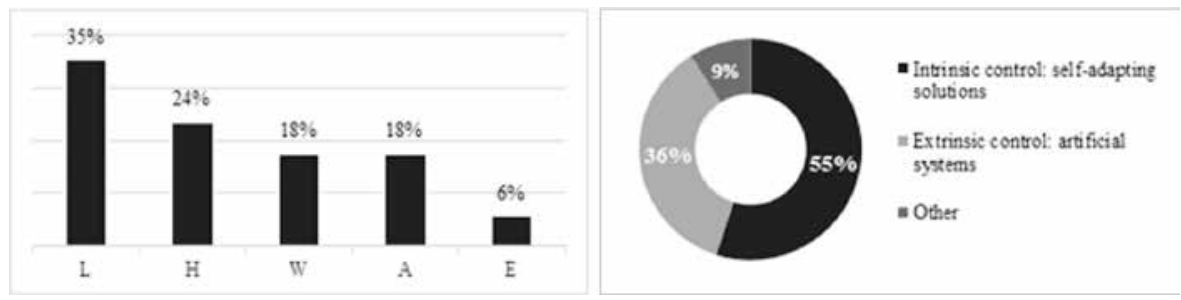

Graph 1: (a) Response to environmental factors. L (Light); H (Heat); W (Water); A (Air), and E (Enbergy); (b) Intrinsic and extrinsic control stimulus. Source: Authors. 
About 55\% of the solutions have Intrinsic Control (systems that self-adjust, without the need of an electromechanical system). These systems use "smart" materials that are responsive to: (a) temperature (such as Shape Memory Alloy [P1]; bimetal [P4]); (b) relative humidity (using hydrogel composites [P9; P10], wood combined with synthetic composites and computer programming [P11]); and (c) energy generated by the bio-based material, from cyanobacteria and bio gel [P7].

Extrinsic Control (artificial systems) represents 36\% of the proposals and includes the use of sensors, processors, and/or actuators, as the systems composed of elastomers [P5] and pneumatic actuators $[\mathrm{P} 2, \mathrm{P} 3, \mathrm{P} 6]$. These solutions aim to reduce the need for maintenance $[\mathrm{P} 2]$ and/or energy consumption of the built spaces [P3, P6] in response to the environmental conditions of light, heat, and air. The remaining $9 \%$ comprise a solution that contributes to cleaning the air during the bio-based material growth phase from fungi [P8]. Regarding deformation, about $73 \%$ of the projects present more than one strategy. Among them, VMP presents the highest level of exploitation (45\%), followed by FSS (30\%), and GS (25\%). Solutions from synthetic composites, such as P2, P3, and P11, explore the VMP under material anisotropy approaches, in which the material direction combined with structural properties can confer different displacements (Charpentier et al., 2017). Pneumatic actuators [P3, P6] and water concentrations [P9, P10, P11] explore the incomprehensibility of fluids. The use of material deformation strategies in experimental processes shows that it is possible to increase the solutions' performance, especially when exploring material anisotropy approaches.

We observed that approaches that use extrinsic controls depend on electricity to respond to the environmental conditions applied to our qualitative analysis. Whereas, the solutions with intrinsic control contribute to: (a) minimizing energy resources and (b) achieving the geometry and functional performance resulting from the association with computational design.

The minimization of energy resources occurs, for instance, under an approach that combines the property of the materials with material deformation strategies as the geometric strategy of Air Flow(er) [P1] (a solution idealized by tensioning SMA and wires, allowing the reversible movements of the panels). As for achieving the geometry and functional performance, it is a result of the association with computational design. The Invert [P4] is an example that presents smart geometry. HygroSkin [P11], in turn, combines the generative algorithm in line with making a composite of material responsive to relative humidity. However, to implement such solutions, we emphasize the importance of identifying the reference climate to develop the facade, as well as conducting critical research on the used materials. The experiments provide support to ensure the solution is appropriate for the environmental conditions of the reference. For example, moisture-sensitive solutions are ideal for humid climates and are not suitable for extremely dry environments (where they are likely to be unresponsive). Similarly, suppose we apply temperature-sensitive solutions, such as P1 and P4, in environments with low temperatures or with minimal incidences of temperature variation. In this case, we will not enhance the performance of the solutions. Another point in the analysis was to identify alternative materials for construction which can contribute to the uncontrolled reduction of natural resources consumption, reduction of $\mathrm{CO}_{2}$ emissions and renewable energy sources. Growing Design has great potential, 
as is the case with the Hortus project [P7], it combines digital design with life which reacts and produces energy through living organic matter (cyanobacteria) that inhabit rigid spaces built using 3D printers. Another Growing Design case regards research that seeks to combine bio-based materials with materials with reversible behavior. An interesting research approach for future developments would be mycelium [P8] as a structure of the facade element associated with SMA [P1] or bimetal [P4], or even strategies in FSS [P3 and P6]. Or substrates of organic materials with a hydration sensitive composite, such as [P10]).

As future developments, we hope to deepen the knowledge related to the performance analysis of projects and issues related to scale, adaptability, biomimetic, and materials. We are interested in combining materials with different deformation strategies, developing sub-components that are adaptable to climatic conditions, and to light and heat gain/loss control. Subsequently, associate sub-components with bio-based wrap materials (replacing conventional materials in civil construction). Thus, we can develop adaptive elements to responsive facades, in favor of a sustainable environment.

\section{Acknowledgments}

This work was supported by the Fundação para a Ciência e a Tecnologia (FCT), SFRH/ BD/144910/2019, and hosted by Centro de Investigação em Arquitetura, Urbanismo e Design (CIAUD) of the Faculdade de Arquitetura da Universidade de Lisboa.

\section{Notes}

1. $4 \mathrm{D}$ printing corresponds to $3 \mathrm{D}$ printing of objects, with the ability to transform the shape when the object, from exposure of the object to a predetermined stimulus (such as submersion in water, exposure to heat, current, and pressure, for example) (Campbell, Tibbits, and Garrett 2014).

\section{References}

Aelenei, Daniel, Laura Aelenei, and Catarina Pacheco. 2016. "Adaptive Façade : Concept , Applications, Research Questions.” Energy Procedia 91: 269-75.

Andrade, Tarciana et al. 2020. "Overview of Nastic Movements in Plants: A Data Collection for Developing Responsive Facades.” In 4th International Conference for Biodigital Architecture \& Genetics, ed. Alberto T. Estévez. Barcelona: iBAG-UIC, 212-21.

AskNature. 2016. "Homeostatic Facade System: Decker Yeadon." https://asknature.org/idea/ homeostatic-facade-system/\#.XH1Oi4hKjIU (March 4, 2019). 
Badarnah, Lidia. 2012. "Towards the Living Envelope: Biomimetics for Building Envelope Adaptation.” Technische Universiteit Delf.

Becker, Tobias, and Simon Huffer. 2015. "Breathing Skins." https://www.breathingskins. com/ (April 9, 2019).

Benyus, Janine M. 2012. Biomimética: Inovação Inspirada Pela Natureza. 6th ed. São Paulo: Pensamento Cultrix Ltda.

Campbell, Thomas A., Skylar Tibbits, and Banning Garrett. 2014. “The next Wave : 4D Printing - Programming the Material World." Atlantic Council (January): 1-15. Research gate.

Charpentier, Victor et al. 2017. "Kinematic Amplification Strategies in Plants and Engineering." Smart Materials and Structures 26(6): 1-30.

Company New Heroes, and Dutch Design Foundation. 2019. "The Growing Pavilion.” https://thegrowingpavilion.com/about/ (June 26, 2020).

DOSU Studio Architects. 2018. "DO|SU Studio Architecture." https://www.dosu-arch.com/ bloom (April 20, 2020).

EcoLogicStudio. 2019. “HORTUS_XL | Astaxanthin.G.” https://www.create-sdu.com/ projects/hortusxlastaxanthing (June 22, 2020).

Estévez, Alberto T. 2020. 4th International Conference for biodigital architecture \& genetics Biodigital Architecture \& Genetics. ed. Alberto T. Estévez. Barcelona: iBAG-UIC.

Fiorito, Francesco et al. 2016. "Shape Morphing Solar Shadings: A Review." Renewable and Sustainable Energy Reviews 55: 863-84.

Grown.bio. 2020. Grow It Yourself Mycelium Packaging Kit.

Gumuchdjian, Philip; Rogers, Richard. 2011. Cidades para um pequeno planeta. [Tradução: Anita Regina Di Marco]. 1 Ed. Barcelona: Gustavo Gilli.

Hensel, Michael Ulrich. 2008. "Performance- Oriented Design Precursors and Potentials." Architectural Design (March 2008).

Karana, Elvin, Davine Blauwhoff, Erik-Jan Hultink, and Serena Camere. 2018. "When the Material Grows: A Case Study on Designing (with) Mycelium-Based Materials." International Journal of Design 12(2): 119-36.

Kirimtat, Ayca, Basak Kundakci, Ioannis Chatzikonstantinou, and Sevil Sariyildiz. 2016. "Review of Simulation Modeling for Shading Devices in Buildings." 53: 23-49.

Knippers, Jan et al. 2016. "Flectofold: Bio-Inspired Kinetic Curved-Line Folding with Distinct Flexible Hinge-Zones.” https://axelkoerner.com/2016/11/15/flectofold/ (March 26, 2020). .2018. "Flectofold Demonstrator, BauBionik Exhibition, Natural History Museum, Stuttgart, 2018.” University of Stuttgart. https://www.itke.uni-stuttgart.de/research/ built-projects/flectofold-demonstrator/ (May 1, 2020).

Kuru, Aysu, Philip Oldfield, Stephen Bonser, and Francesco Fiorito. 2019. "Biomimetic Adaptive Building Skins: Energy and Environmental Regulation in Buildings.” Energy and Buildings 205: 109544.

Lienhard, Julian et al. 2012. "Flectofin ${ }^{\circledR}$ A Hinge-Less Flapping Mechanism Inspired by Nature International." International Bionic-Award 2012: 18.

Lift Architects. “The Air Flow(Er).” http://www.liftarchitects.com/air-flower (June 7, 2019).

Lotti, M. G. M. 2015. Processo de desenvolvimento e implantação de sistemas, medidas e práticas sustentáveis com vista a certificação ambiental de empreendimentos imobiliários: estudo de caso: Empreendimento Bairro Ilha Pura - Vila Dos Atletas 2016. Projeto 
de Graduação (Engenharia Civil) - Escola Politécnica, Universidade Federal do Rio de Janeiro, Rio De Janeiro, 2015.

Materiability Research Group. "Hydroceramic.” 2013. http://materiability.com/portfolio/ hydroceramic/ (March 14, 2020).

Menges, Achim. 2012. "HygroScope: Morfologia Meteorossensitiva." http://www.achimmen ges.net/?p=5083 (March 14, 2019).

Menges, Achim, and Sean Ahlquist. 2012. Computational Design Thinking. London: John Wiley \& Sons Ltda.

Queiroz, Natália de. 2015. “Artefatos Geradores de Microclima: Biommimética, Parametrização e Prototipagem Rápida Na Busca Por Soluções Bioclimáticas Para Clima Quente e Úmido." Dissertação de mestrado, Universidade Federal de Pernambuco, Recife, PE, Brasil.

Reichert, Steffen, Achim Menges, and David Correa. 2014. "Computer-Aided Design Meteorosensitive Architecture : Biomimetic Building Skins Based on Materially Embedded and Hygroscopically Enabled Responsiveness." Computer-Aided Design 60: 50-69.

Rathee, Akanksha et al. 2013. "Hydroceramic." https://iaac.net/project/hydroceramic/ (March 14, 2020).

Sack-Nielsen, Torsten. 2017. "Performance through Thickfolds: Approaching Climate-Responsive Behaviours through Shape, Materialisation and Kinematics." Aarhus School of Architecture.

Santana Neto, Ernesto José de, and Robson Canuto da Silva. 2016. “Computação Material : Um Estudo Sobre a Atualização Geométrica de Elementos Vazados Na Arquitetura." In SIGraDi 2016, XX Congreso de La Sociedad Ibero-Americana de Gráfica Digital, Buenos Aires: SIGraDi 2016, 43-49.

Schleicher, Simon et al. 2015. "A Methodology for Transferring Principles of Plant Movements to Elastic Systems in Architecture." In CAD Computer Aided Design, Elsevier Ltd, 105-17.

Sung, Doris Kim. 2016. "Smart Geometries for Smart Materials : Taming Thermobimetals to Behave." Journal of Architectural Education ISSN: 70(1): 96-106.

Sydney Gladman, A. et al. 2016. "Biomimetic 4D Printing." Nature Materials 15(4): 413-18.

TBM Designs. 2020. "InVert Self-Shading Window System: Flipping Energy Efficiency on Its Head." https://www.tbm-designs.com/about (February 20, 2021).

U.S. Green Building Council. 2009. LEED Reference Guide for Green Building Design and Construction For the Design, Construction and Major Renovations of Commercial and Institutional Buildings Including 2009 Edition USGBC Membership.

Vazquez, Elena, Clive Randall, and Jose Pinto Duarte. 2019. "Shape-Changing Architectural Skins A Review on Materials, Design and Fabrication Strategies And.” Journal of Facade Design and Engineering 7(2): 91-102.

Resumen: El conocimiento actual demuestra la expansión de las propuestas de las fachadas receptivas recurriendo a enfoques biomiméticos, investigación de materiales y diseño 
algorítmico. Este trabajo recoge las tendencias en materiales y tecnologías que contribuyen al control térmico y ambiental de los edificios a favor de la sostenibilidad. Analizamos once propuestas de fachadas e instalaciones, los diseños elegidos cumplen con los siguientes criterios: presentar diferentes estrategias reversibles de transformación del material y/o materiales de base biológica. En obras futuras, pretendemos proponer nuevas soluciones de fachada receptiva para contribuir a la sostenibilidad de los edificios.

Palabras clave: Biomimética y Diseño - Adaptación climática - Fachada receptiva - Deformación del material - Diseño en crecimiento - Materiales de base biológica - Innovación - Material receptivo - Sostenibilidad

Resumo: O conhecimento atual demonstra a expansão das proposições de fachadas responsivas recorrendo a abordagens biomiméticas, pesquisa de materiais e design algorítmico. Este trabalho contempla tendências em materiais e tecnologias que contribuem para o controle térmico e ambiental das edificações em prol da sustentabilidade. Foram analisadas onze propostas de fachadas e instalações. Os projetos escolhidos atendem aos seguintes critérios: apresentar diferentes estratégias reversíveis de transformação do material e / ou materiais de base biológica. Em trabalhos futuros, pretendemos propor novas soluções de fachada responsiva para contribuir para a sustentabilidade dos edifícios.

Palavras chave: Biomimética e Design - Adaptação ao clima - Fachada responsiva - Deformação de materiais - Design crescente - Materiais biológicos - Inovação - Material responsivo - Sustentabilidade 